Chirurgia (2020) 115: 783-791

No. 6, November - December Copyright@ Celsius

\title{
Single Dose of Sildenafil and Atorvastatin Increase Skin Survivability, but only Atorvastatin Increase Nitric Oxide in Rat Ischeamia Reperfusion Model
}

\section{Panagiotis Theofanis Arkoumanis ${ }^{1,2^{*}}$, Theodosios Theodosopoulos ${ }^{3}$, Georgios Gkiokas ${ }^{3}$,Antonios Vezakis ${ }^{3}$, Athanasios Dellis ${ }^{3,4}$, Panagiotis Konstantopoulos',Dominic Yue ${ }^{2}$, David Zargaran², Lydia Ioannidi², Vasilios Spyropoulos ${ }^{2}$}

'Laboratory for Experimental Surgery and Surgical Research "N. S. Christeas", Medical School, National and Kapodistrian University of Athens, Greece

${ }^{2}$ Department of Plastic and Reconstructive Surgery, Chelsea and Westminster Hospital, London, United Kingdom

${ }^{3}$ 2nd Department of Surgery, Aretaieion Academic Hospital, School of Medicine, National and Kapodistrian University of Athens, Greece

${ }^{4} 1$ st Department of Urology, Laikon General Hospital, School of Medicine, National and Kapodistrian University of Athens, Greece

${ }^{*}$ Corresponding author:

Panagiotis Theofanis Arkoumanis, MD Laboratory for Experimental Surgery and Surgical Research "N. S. Christeas" Medical School, National and Kapodistrian University of Athens, Greece Department of Plastic and Reconstructive Surgery, Chelsea and Westminster Hospital, London, United Kingdom Flat 19C, Room 5024, Doughty House, Netherton Grove, London, SW109TQ E-mail: arkoufan@gmail.com
Received: 25.04 .2020 Accepted: 22.06.2020

\section{Rezumat}

Administrarea de sildenafil și atorvastatină monodoză crește șansele de supravietuire ale pielii, dar doar administrarea de atorvastatină sporește productia de monoxid de azot în ischemie-reperfuzie modelată pe sobolani

Context:Leziunile de ischemie-reperfuzie (IRI) sunt o provocare frecventă în reconstrucția tisulară. Atorvastatin şi Sildenafil au fost studiate din perspectiva efectelor lor de protecție şi/sau terapeutice asupra diverselor sisteme de organe cu IRI. Obiectivul prezentului studiu este compararea tratamentului prealabil cu Atorvastatin şi Sildenafil monodoză în cazuri de stres oxidativ/ nitro-oxidativ şi necroză de lambou dermic.

Materiale şi metode: Patruzeci şi cinci de şobolani SpragueDawley alocați aleatoriu în trei grupuri egale $(n=15)$. Grupul A: grup de control, tratat intraperitoneal cu ser fiziologic; Grupul B: grup tratat cu sildenafil; şi Grupul C: grup tratat cu atorvastatină S-a efectuat decolare de lambou şi ocluzie de arteră epigastrică inferioară la toți şobolanii la treizeci de minute de la administrarea medicației. S-au evaluat mieloperoxidaza, nivelurile malondialdehidei, şi sintetaza de monoxid de azot indusă la 12 ore de la reperfuzie. Şansele de supraviețiire ale lambourilor au fost analizate la 7 zile de la efectuarea intervenției. 
Rezultate:S-a detectat reducere substanțială în grupurile tratate cu slidenafil şi atorvastatină. Valorile mieloperoxidazei au urmat un model similar şi, interesant, nivelurile măsurate ale malondialdehidei au fost semnificativ mai reduse în grupul tratat cu slidenafil. Dimpotrivă, sintetaza de monoxid de azot indusă din atorvastatină a fost semnificativ mai ridicată în grupul tratat cu atorvastatină.

Concluzie: Tratamentul cu atorvastatină sau sildenafil monodoză sporeşte aproape identic şansele de supraviețuire ale lambourilor. Totuşi, doar tratamentul cu atorvastatină sporeşte semnificativ exprimarea de sintetază de monoxid de azot indusă.

Cuvinte cheie: leziune de ischemie-reperfuzie, sildenafil, atorvastatină, lambou, şobolan, lambou dermic, artera epigastrică inferioară, chirurgie experimentală

\section{Abstract}

Background: Ischeamia reperfusion injury is a frequent challenge during tissue reconstruction. Atorvastatin and Sildenafil, have been studied for their protective and/or therapeutic effects on various organ systems subjected to IRI. The aim of the present study was to compare a single dose of Atorvastatin and Sildenafil pretreatment on acute oxidative/nitrosative stress and the subsequent dermal flap necrosis.

Materials and methods: Forty-five Sprague-Dawley rats, were randomly allocated into three equal groups $(\mathrm{n}=15)$ : Group $\mathrm{A}$ : Control rats treated with intraperitoneal saline, Group B: Sildenafil group, and Group C: atorvastatin group. All rats underwent flap elevation and inferior epigastric artery occlusion thirty minutes after drug administration. Myeloperoxidase activity, malondialdehyde levels and inducible nitric oxide synthase activity were evaluated 12 hours after reperfusion. Flap survivability was analysed 7 days after the procedure.

Results: Statistically significant reduction was detected in sildenafil and atorvastation. Measurements of myelopyroxidase followed a similar pattern, interestingly malonadehyde levels measured to be significantly lower in the sildenafil group. Contrary, iNOS activity atorvastatin was significantly elevated in atorvastatin group.

Conclusion: The single dose of atorvastatin or sildenafil increase flap survivability almost equally, however only atorvastatin enhances significantly iNOS expression

Key words: ischeamia-reperfusion injury, sildenafil, atorvastatin, flaps, rat, inferior epigastric artery skin flap, experimental surgery

\section{Introduction}

Ischeamia - reperfusion injury (IRI) is a phenomenon frequently encountered in surgical and clinical conditions accounting for loss of anatomical and functional integrity of tissues while elevating rates of morbidity and mortality $(1,2)$.

Free tissue reconstruction has become a common challenge during the reconstruction of large defects secondary to burns, tumour ablations, infections or trauma where the satisfactory blood flow through the flap is quite important (3). In the past two decades the success rates in free tissue reconstruction experienced a steady increase ranging between $92 \%$ and $99 \%$ in international medical institutes (4). However the current flap loss rates ranges between $2.9 \%$ and $4.3 \%$ (5). Paradoxically, in another study specific to breast reconstruction procedures the estimated complication percentage rest in $27.9 \%$ (6) 
whereas in a study focused in head and neck reconstruction the complications were more than quarter $(32.6 \%)$ of all the cases (7). Unfortunately, the more complication rates increase more the post operative costs (8).

Specifically, as a flap is raised from its bed, the flap stops acting as a paragon of thermoregulation and behaves as a tissue attempting to regain its hemodynamic balance. The consequent disturbance of the blood circulation taking place during the elevation of the flap as well as, metabolic and anatomic changes may result in distal necrosis (9-11).

A number of experimental and clinical studies have been investigated to improve flap viability by influencing the flap metabolism after elevation, with the use of medications such as free radical scavengers and prostaglandin inhibitors (12-13). Sildenafil citrate (SC) is a competitive and potent inhibitor of cyclic guanosine monophosphate (cGMP)-specific phosphodiesterase type 5(PDE-5). PDE-5 specifically inhibits nitric oxide (NO)/GMP pathway in vascular smooth muscles inducing vasodilatation and platelet aggregation (14). Even though sildenafil is prescribed for improvement of erectile function recently published experimental trials have indicated their potential therapeutic role in the reduction of the harmful effects of IRI in various organ system $(12,13)$.

Atorvastatin (AT) is a 3-hydroxy-3-methylglutaryl-CoA (HMG-CoA) reductase inhibitor, a key enzyme in liver cholesterol biosynthesis responsible for catalyzing the reduction of HMG-CoA in mevalonate (15). However, statins seem to exert independent effects on cholesterol levels, called pleiotropic effects. Particularly, the Rac protein pathway singling and the endothelial nitric oxide synthase (eNOS) expression has been demonstrated to be related with reactive oxygen species production and subsequently to IRI. Hence, two experimental studies have investigated the the impact of atorvastatin in ischeamic flaps establishing the positive effects of atorvastatin on IRI $(16,17)$.

In the present day, there is no sufficient data comparing the putative ameliorate antioxidative and anti-inflammatory properties of PDE-5 inhibitors and HMG-CoA reductase inhibitors in an IRI animal model.

\section{Material and Methods}

Animal experimentation was performed in Laboratory for Experimental Surgery and Surgical Research "N.S. Christeas" (Athens, Attica, Greece) and the protocol was evaluated and approved by the and the protocol was evaluated and approved by the Veterinary Service of the Prefecture of Athens (ref. no. 5175-June 2007) in accordance with Greek legislation (p.d. 160/91) and European Community regulations (directive 309 of 1986; license according to E.U. legislation). Experiments were performed according to the Presidential Decree 56/2013 which harmonizes Greek legislation with the European Community Directive 63/2010 on the Protection of Animals Used for Scientific Purposes.

Forty-five male Sprague-Dawley rats (Rattus norvegicus domestica) weighting 220-270g, were enrolled in this experiment. Prior to the surgery the animals were kept in comfortable cages at 22 to $25 \mathrm{C}$ with free access to food and tap water for 1-week acclimation period and strict sanitary conditions.

Rats were randomly distributed into the following three groups.

- Group A: Control group (flap, 7 hours of ischeamia, $0.5 \mathrm{~mL}$ saline injection; $\mathrm{n}=15$ )

- Group B: Sildenafil group( flap, 7 hour of ischeamia, $10 \mathrm{mg} / \mathrm{kg}$ sildenafil intraperitoneal injected, $\mathrm{n}=15$ ) (Sildenafil/Sandoz 50 mg, Biochemiestrasse 10, 6250, Kundl, Austria).

- Group C: Atorvastatin group (flap, 7 hour of ischeamia, $10 \mathrm{mg} / \mathrm{kg}$ atorvastatin intraperitoneal injected, $\mathrm{n}=15$ ) (Lipitor Lipitor $10 \mathrm{mg}$, Pfizer Hellas A.E., Mesogeion Av.243, 15451, N. Psichiko, Athens).

Sildenafil (Sildenafil/Sandoz $50 \mathrm{mg}$, Biochemiestrasse 10, 6250, Kundl, Austria) 
tablets and Atorvastatin (Lipitor Lipitor 10 mg, Pfizer Hellas A.E., Mesogeion Av.243, 15451, N. Psichiko, Athens) were dissolved in saline. Both substances are characterized for their lipophilicity. Ketamine hydrochloride $(50 \mathrm{mg} / \mathrm{kg})$ (KETAMIN-ACTAVIS inj.sol (im, iv) $10 \mathrm{mg} / \mathrm{ml}$, IФET A.E.) and xylazine hydrochloride $(2,5 \mathrm{mg} / \mathrm{kg})\left(\mathrm{ROMPUN}^{\mathrm{B}}\right.$ Bayer Animal Health GmbH D-51368 Leverkusen Germany) was used to anaesthetized the animals. Following the induction of anaesthesia, a left island skin flap measuring $3 \times 6 \mathrm{~cm}$ was drawn and elevated on the rat's abdomen, as described by Petry and Wortham.(18) The flaps were transected proximally, leaving the inferior epigastric vessels as the only connection. A silicone sheath (Bioplexus, Los Angeles, CA) was placed underneath the flap in order to prevent vascular invasion. All flaps were subjected to 7 hour of ischeamia prior to revascularization with a $7-\mathrm{mm}$ micro clamp (S\&T, Neuhausen, Switzerland) placed on the vascular pedicle: I/R control group A 7 hour of ischeamia + intraperitoneal $0.5 \mathrm{~mL}$ saline injection 3 minutes prior to micro clamp removal, I/R sildenafil group $\mathrm{B}(7$ hour of ischeamia $+10 \mathrm{mg} / \mathrm{kg}$ sildenafil intraperitoneal injected 3 minutes prior to micro clamp removal and $\mathrm{I} / \mathrm{R}$ atorvastatin group $\mathrm{C} 7$ hour of ischeamia $+10 \mathrm{mg} / \mathrm{kg}$ atorvastatin intraperitoneal injected 3 minutes prior to micro clamp removal. After the ischeamia period all flaps underwent 12 hour of reperfusion inducing ischeamia reperfusion injury. Blood samples were collected following the completion of the procedure. The flap survivability was monitored until the seventh post-operative day. All animals were euthanized by inhaling concentrated $30 \% \mathrm{CO} 2$. All groups were allowed to recover and were housed individually in the animal facilities of the institution under controlled temperature, humidity, and photoperiod conditions.The sum of the cohort was closely monitored everyday for weight fluctuations and other signs of complication. No kind of antibiotic was administered through the study. Collars made of radiologic film were applied to all animals to avoid autocannibalization of the flaps. Any animals that cannibalized their denervated flaps were eliminated from the study.

\section{Flap Necrosis}

On the $7^{\text {th }}$ day, in all animals (fifteen rats in each group) the flap survivability was evaluated with digital images (iPhone 7; Apple, California, USA) and for further objective analysis the Universal Desktop Ruler v3.5.3364 software (AVPSoft, Voronezh, Russia) was used. Skin colour, eschar formation together with the residual viable area was expressed as a percentage of the flap area in order to estimate the flap necrosis.

\section{Blood Collection}

Blood samples were collected, (after a 12-h reperfusion) at baseline (day of surgery, D1) postoperatively using capillary tubes introduced into the medial retro-orbital venous plexus under light ether anesthesia. The serum was separated by centrifugation at $3000 \mathrm{rpm}$ for $10 \mathrm{~min}$.

\section{Malondialdehyde MDA}

Malondialdehyde (MDA) is a byproduct of lipid peroxidation and thus is used as a parameter to determine the extent of lipid peroxidation. Lipid peroxidation levels were determined via the investigation of serum MDA levels using a commercially available kits MDA (Malondialdehyde) from ELISA Kit, Elabscience, Elabscience Biotechnology Co., Ltd, (Wuhan, China) All kits used the sandwich ELISA principle, and the optical density (OD) was measured spectrophotometrically at a wavelength of $450 \pm 2 \mathrm{~nm}$ with the use of the Bio-Rad 680 microplate reader. MDA level were expressed in $\mathrm{nmol} / \mathrm{mg}$.

\section{MPO}

MPO (Myeloperoxidase) activity - an indicator 
of neutrophil accumulation - was assessed by commercially available kits MPO from ELISA Kit, Elabscience, Elabscience Biotechnology Co., Ltd, (Wuhan,China). All kits used the sandwich ELISA principle, and the optical density (OD) was measured spectrophotometrically at a wavelength of $450 \pm 2 \mathrm{~nm}$ with the use of the Bio-Rad 680 microplate reader MPO activity was expressed as $\mathrm{mU} / \mathrm{mg}$.

\section{iNOS}

Nitric Oxide Synthase activity was assessed by commercially available kits Rat NOS2/ iNOS (Nitric Oxide Synthase 2, Inducible NOS activity was expressed in $\mathrm{ng} / \mathrm{mL}$ ). All kits used the sandwich ELISA principle, and the optical density (OD) was measured spectro-photometrically at a wavelength of $450 \pm 2 \mathrm{~nm}$ with the use of the Bio-Rad 680 microplate reader NOS activity was expressed as $\mathrm{ng} / \mathrm{mL}$.

\section{Statistical Analysis}

Prior to the selection of the appropriate criteria, data were analysed for normality of the distribution and homoscedasticity of the residuals using the Shapiro-Wilk and Levene's test respectively. Since these prerequisites were satisfied, one way analysis of variance (ANOVA) was employed and when the F-value was significant between groups Gabriel and Games-Howell multiple comparisons tests were applied appropriately. The results were presented descriptively with their means \pm standard deviation and represented with bar charts. Subsequent to the ANOVA, Discriminant Analysis (DA) was conducted in order to evaluate which biochemical indices distinguish among treatment regimes. All the variables were compared with Pearson's $r$ correlation coefficient test and only variables without significant correlation between them were included in the model. DA results were presented with canonical correlation, Wilks' Lambda evaluated with chi-square test, and standardized canonical discriminant function coefficient. The higher the absolute values of the coefficients the greater the contribution of the respective variable(s) to the discrimination between groups. Small Lambda values (close to zero) and significant chi-square indicate the differences between the groups, while a high canonical correlation explains the better the variance of the models. DA was performed using the stepwise algorithm given the amount of variables and the sample size. Twosided tests were used and any $\mathrm{p}^{-}$value below 0.05 was considered statistically significant. All analyses and graph creation were performed using IBM $^{\circledR}$ SPSS $^{\circledR}$ Statistics software version 22 (Armonk, NY).

\section{Results}

Gabriel post hoc test for slightly unequal sample sizes or the Games-Howell for unequal variances was employed appropriately due to four mortalities (from two all groups). In the remaining animals all the operative and invasive procedures were well tolerated without any irreversible complications, and the animals maintained normal appetite and body weight fluctuation.

\section{Flap Necrosis}

At the end of the experiment FNA between group A and B differed statistical significantly $(42.89 \% \pm 8.84 \%$ vs. $34.46 \% \pm 7.36 \%)$. In a similar fashion statistical significantly differences in FNA were observed between groups A and C $(42.89 \% \pm 8.84 \%$ vs. $32.42 \%$ $\pm 6.93 \%)$ However, none of the treatment regimes affected superiorly the viability of the flaps.

\section{MDA, MPO and iNOS}

During the acute phase of IRI (12h) remarkably elevated oxidative stress was observed as shown by the abnormalities of the biochemical indices. In particular MPO levels differed significantly between group $\mathrm{A}$ and $\mathrm{B}$ (8548.53 pg/mL $\pm 5040.5 \mathrm{pg} / \mathrm{mL}$ vs. 2860.72 $\mathrm{pg} / \mathrm{mL} \pm 1315.08 \mathrm{pg} / \mathrm{mL}$ ) and also between group $\mathrm{A}$ and $\mathrm{C}(8548.53 \mathrm{pg} / \mathrm{mL} \pm 5040.5$ 
$\mathrm{pg} / \mathrm{mL}$ vs. $3426.22 \mathrm{pg} / \mathrm{mL} \pm 1332.73 \mathrm{pg} / \mathrm{mL}$ ). No significant differences in MPO levels were detected between groups B and C. However, MDA levels differed significantly not only among control and treatment groups $(136.66 \mathrm{ng} / \mathrm{mL} \pm 16.76 \mathrm{ng} / \mathrm{mL}$ vs. $76.18 \mathrm{ng} / \mathrm{mL}$ $\pm 13.9 \mathrm{ng} / \mathrm{mL}$ for group B and $90.97 \mathrm{ng} / \mathrm{mL} \pm$ $12.9 \mathrm{ng} / \mathrm{mL}$ for group $\mathrm{C}$ respectively) but also between them. Contrary to the above patterns iNOS activity was significantly elevated in group C vs. group B $(5.67 \mathrm{ng} / \mathrm{mL} \pm 0.69$ $\mathrm{ng} / \mathrm{mL}$ vs. $4.61 \mathrm{ng} / \mathrm{mL} \pm 0.96 \mathrm{ng} / \mathrm{mL}$ respectively) although no significant differences were encountered between treatment groups and control group. The results of dermal flap necrosis and biochemistry according to the different treatment modalities are represented in Fig. 1

\section{Correlations}

A powerful positive correlation was observed between FNA and all biochemical indices among all groups (Table 1). These findings address FNA as the dependent variable and the primary outcome of the study, so it was not included in the DA. Correlations between biochemical values were performed during DA
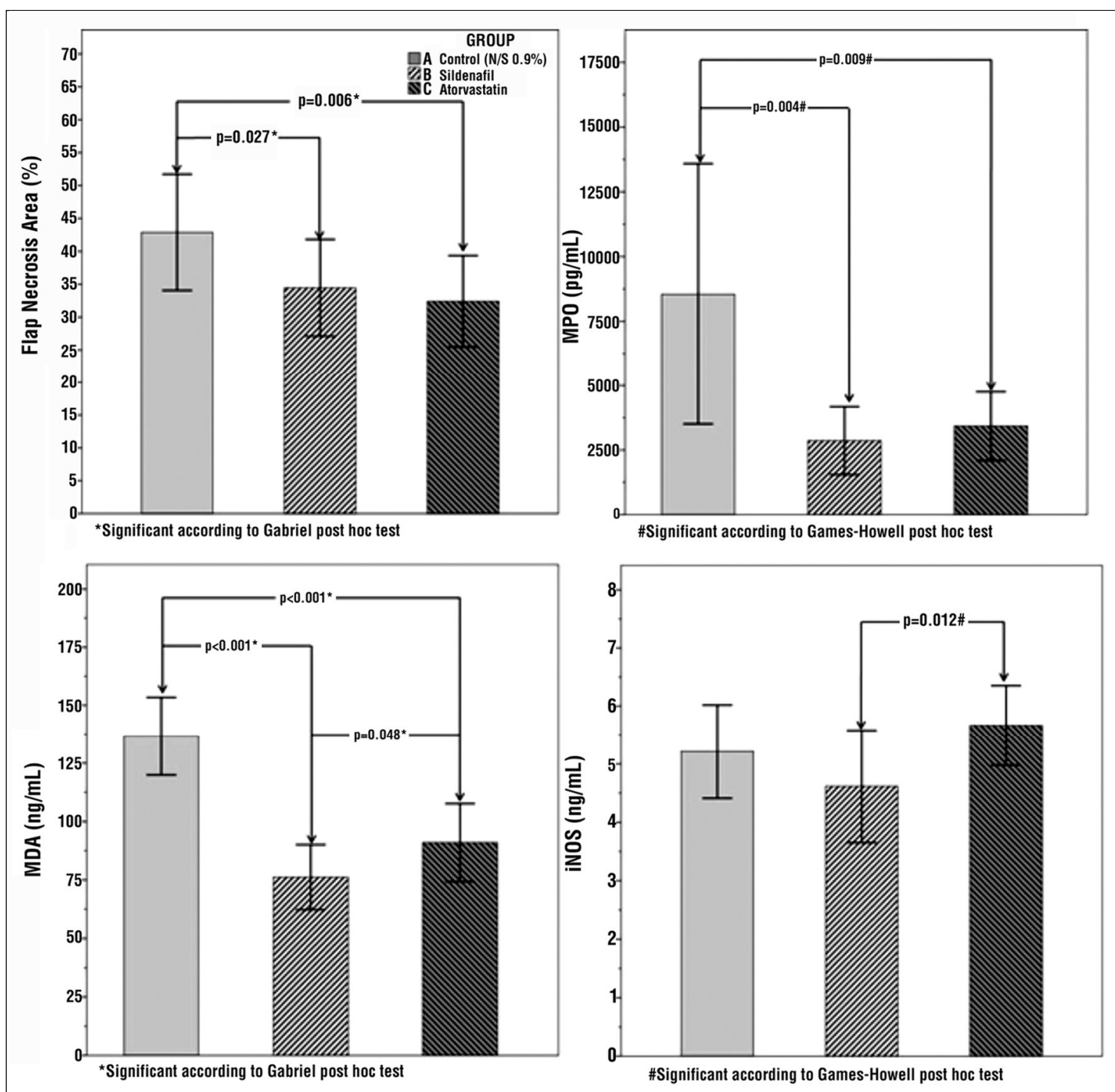

Figure 1. 
as presented later (Table 2). Since the study comprised three groups differentiated by three biomarkers two discriminant functions $(\mathrm{k}-1)$ were conducted; the first function maximally separated the groups and the second separated the groups on variance not yet explained by the first function. The results from the DA demonstrated that $1^{\text {st }}$ function has high canonical correlation (0.885) explaining the $93 \%$ of the variance and the $2^{\text {nd }}$ function has a canonical correlation (0.462) explaining the rest $7 \%$ of the variance. Since both functions were statistically significant it was worthwhile keeping both at the interpretation of the results (Table 3). Standardised canonical discriminant function coefficients highlighted the impact of MDA in function-1 and iNOS function-2, while MPO was excluded from the algorithm. The overall accuracy of the model was $81.6 \%$. In brief, these results indicate that MDA was powerfully associated with group A, whereas iNOS was associated with the profile of group $\mathrm{C}$ ( Table 4 ).

Since the focus of the DA was to determine how the groups differ according to biochemical markers and not to create a
Table 1.

\begin{tabular}{lccc}
\hline GROUPS & FNA-MPO & FNA-MDA & FNA-iNOS \\
\hline A & $0.782^{\star *}$ & $0.732^{\star *}$ & $0.623^{\star}$ \\
\hline B & $0.557^{*}$ & $0.702^{\star *}$ & $0.650^{\star}$ \\
\hline C & $0.593^{*}$ & $0.660^{*}$ & $0.684^{*}$ \\
\hline * Correlation was significant at the 0.05 level according to Pearson correlation \\
coefficient. \\
** Correlation was significant at the 0.01 level according to Pearson correlation \\
coefficient.
\end{tabular}

classification model the discriminant scores (although calculated) were omitted from the presentation.

\section{Discussion}

During elective reconstructive surgery with free flap transfer, IRI may occur and compromise flap viability, increase patient morbidity, prolong hospitalization disproportionately affect medical costs (19). Since this complication can not be underestimated, several anecdotal preventive and therapeutic modalities have been described. These range from transient ischemic preconditioning, to hyperbaric oxygen and the use of the human

Table 2. Within groups correlations coefficients

\begin{tabular}{lcccc}
\hline \multicolumn{4}{c}{ Pooled Within-Groups Matrices } \\
\hline Correlation & MPO & MDA & iNOS \\
\hline & MPO & $1.000^{\star \star \star}$ & $0.465^{\star \star \star}$ & $0.335^{\star \star \star}$ \\
\hline MDA & & 1.000 & $0.310^{\star \star \star}$ \\
\hline iNOS & & & 1.000 \\
\hline
\end{tabular}

${ }^{\star * \star}$ Correlation was significant at the 0.05 level according to Pearson correlation coefficient.

Table 3. Canonical correlations and Wilks' Lambda evaluated with chi-square. The above results indicate the discrimination accuracy of the DA

\begin{tabular}{lcccc}
\hline \multicolumn{5}{c}{ Eigenvalues } \\
\hline Function & Eigenvalue & \% of Variance & Cumulative \% & Canonical Correlation \\
\hline 1 & $3.612^{\mathrm{a}}$ & 93.0 & 93.0 & .885 \\
\hline 2 & $.271^{\mathrm{a}}$ & 7.0 & 100.0 & .462 \\
\hline
\end{tabular}

aFirst 2 canonical discriminant functions were used in the analysis

\begin{tabular}{lcccc}
\hline \multicolumn{5}{c}{ Wilks' Lambda } \\
\hline Test of Function(s) & Wilks' Lambda & Chi-square & df & Sig. \\
\hline 1 through 2 & .171 & 61.003 & 4 & .000 \\
\hline 2 & .787 & 8.266 & 1 & .004 \\
\hline
\end{tabular}


Table 4. Standardised canonical discriminant function coefficients highlighted the effect of MDA and iNOS in the FNA consecutive to IRI

\begin{tabular}{lcc}
\hline \multicolumn{3}{c}{ Standardized Canonical Discriminant Function Coefficients } \\
\hline & \multicolumn{3}{c}{ Function } \\
\hline MDA & 1 & 2 \\
\hline iNOS & 1.049 & -.080 \\
\hline
\end{tabular}

adenovirus-mediated gene transfer method (20-22). In the present experimental study, we choose to administer a single dose of a well-known statin and a type-5 phosphodiesterase inhibitor as preventive treatment for rat epigastric skin flap ischeamia reperfusion.

To be specific, sildenafil can induce vasodilation, reduce inflammatory markers while promoting angiogenesis through stimulation of HIF-1a transactivation and modulate the NO/cGMP pathway thus stimulating neovascularization (23-25) On the other hand atorvastatin can reduce oxidative stress production, ROS synthesis, NO production and inflammatory cytokine mediation (26). These multiple actions of statins are termed pleiotropic and have been the subject of research in the last decade (27) To our knowledge, this is the first experimental effort to explore the beneficial effects of a single dose of these drugs in ischeamic skin flap. In our study, there was a statistically significant improvement in skin survivability in both therapy schemes, however none was proven superior to the other.

Therapeutic approaches in ischeamia reperfusion focus in antioxidant treatment as during reperfusion free radical cause the main damage in tissues (28) Literature already acknowledge that statins can improve the impact of ischeamia reperfusion in many organs $(29,30)$ Sildenafil has also proven to decrease lipid per oxidation and reactive oxygen species production in lung ischeamia reperfusion experiment (30). However optimal dose of these medications are yet to be defined for ischeamia reperfusion. Interestingly, our data showed that a single administration of sildenafil and atorvastatin as monotherapy suffice to increase tissue survivability as well as to reduce biochemical markers of tissue injury as well as expression of inflammation and oxidative stress like MDA, MPO and iNOS. Tu et al. evaluated the effects of atorvastatin after cerebral ischemia/reperfusion injury. It was found that atorvastatin treatment exhibit neuroprotective effect and decrease lipid peroxidation as MDA levels indicate (29). In the same therapeutic approach, the administration of sildenafil has been found to enhanced viable flap area (31). It has been also found to pose anti-inflammatory properties resulting in the protection of ischemiareperfusion-induced AKI (32).

According to our results, a single dose of atorvastatin or sildenafil present beneficial role in MPO levels as both molecules prove capable of reducing them. Additionally, no significant differences were detected between sildenafil and atorvastatin groups. It is worth mentioning that the pattern of iNOS activity is significantly elevated in atorvastatin versus the sildenafil group. Finally, a powerful positive correlation was observed between skin survivability and biochemical values among all study groups while a single dose of atorvastatin is strongly associated with iNOS levels.

\section{Conclusion}

In summary, in skin ischeamia reperfusion injury, oxidative injury and inflammatory response are induced, while a single administration of atorvastatin and sildenafil protects against injury without any detected adverse effects in peripheral blood. Furthermore even if both drugs showed similar effects, only Atorvastatin was associated iNOs stores. This effect may translate into improved long-term protective effects against dermal ischeamia reperfusion injury. Nevertheless, further studies in skin ischeamia reperfusion are required for validation of these finding and possible provision of a therapeutic scheme prior to tissue reconstruction operations. 


\section{Declaration of Interest}

The authors report no conflicts of interest. The authors alone are responsible for the content and writing of the paper.

\section{Ethics Approval}

The protocol was approved by Veterinary Service of the Prefecture of Athens (ref. no. 5175 - June 07).

\section{Reference}

1. de Groot H, Rauen U. Ischemia-reperfusion injury: proc- esses in pathogenetic networks: a review. Transplant Proc. 2007;39(2): 481-484.

2. Carden DL, Granger DN. Pathophysiology of ischaemia-reperfusion injury. J Pathol. 2000;190(3):255-266.

3. Wei FC, Mardini S. Flaps and Reconstructive Surgery. 2nd ed. Philadelphia: Elsevier; 2016, 872 p.

4. Schusterman MA, Miller MJ, Reece GP, Kroll SS, Marchi M, Goepfert H. A single center's experience with 308 free flaps for repair of head and neck cancer defects. Plast Reconstr Surg. 1994;93(3):472-480.

5. Pohlenz P, Blessmann M, Heiland M, Blake F, Schmelzle R, Li L. Postoperative complications in 202 cases of microvascular head and neck reconstruction. J Craniomaxillofac Surg. 2007;35(6/7): 311-315.

6. Mehrara BJ, Santoro TD, Arcilla E, Watson JP, Shaw WW, Da Lio AL. Complications after microvascular breast reconstruction: experience with 1195 flaps. Plast Reconstr Surg. 2006;118(5): $1100-1111$

7. Le Nobel GJ, Higgins KM, Enepekides DJ. Predictors of complications of free flap reconstruction in head and neck surgery: analysis of 304 free flap reconstruction procedures. Laryngoscope. 2012; 122(5):1014-1019.

8. Fischer JP, Sieber B, Nelson JA, Cleveland E, Kovach SJ, Wu LC, et al. Comprehensive outcome and cost analysis of free tissue transfer for breast reconstruction: an experience with 1303 flaps. Plast Reconstr Surg. 2013;131(2):195-203.

9. Kerrigan CL, Daniel RK. Pharmacologic treatment of the failing skin flap. Plast Reconstr Surg 1982;70:541-9.

10. Kerrigan CL. Skin flap failure: pathophysiology. Plast Reconstr Surg 1983;72:766-77.

11. Kerrigan CL, Hjortdal VE. Skin flap physiology and patho-physiology. In Barrdach J, editor. Local flaps and free skin grafts. St. Louis, MO: Mosby; 1992. p 24-41.

12. Botha $P$, MacGowan GA, Dark JH. Sildenafil citrate augments myocardial protection in heart transplantation. Transplantation 2010; 89(2):169-177.

13. Shih PK, Cheng CM, Li HP, et al. Pretreatment with sildenafil alleviates early lung ischemia-reperfusion injury in a rat model. $J$ Surg Res. 2013; 185(2):e77-e83.

14. Das A, Xi L, Kukreja RC. Phosphodiesterase-5 inhibitor sildenafil preconditions adult cardiac myocytes against necrosis and apoptosis. J Biol Chem. 2005; 280(13): 12944-12955.
15. Page C, Curtis M, Sutter M, Walter M, Hoffman B. Integrated Pharmacology. 1st ed. Edinburgh: Mosby, 1997; pp. 267-70.

16. Jia YC, Xu J, Chen HH, Kang QL, Chai YM. The Effect of Atorvastatin on the Viability of Ischemic Skin Flaps in Diabetic Rats. Plast Reconstr Surg. 2017;139(2):425e-433e.

17. Chen JX, Chiu CW, Shih PK. The effect of atorvastatin on survival of rat ischemic flap. Kaohsiung J Med Sci. 2013;29(4):187-193.

18. Petry, J. J., and Wortham, K. A. The anatomy of the epigastric flap in the experimental rat. Plast. Reconstr. Surg. 74: 410, 1984.

19. Wang $\mathrm{Y}$, Orbay H, Huang C, Tobita M, Hyakusoku H, Myamoto M, et al. Preclinical efficacy of slow- release bFGF in ischemiareperfusion injury in a Dorsal Island skin flap model. J Reconstr Microsurg. 2013;29(5):341-6.

20. Wang WZ, Fang XH, Stephson LL, Khiabani KT, Zamboni WA. Melatonin reduces ischeamia/reperfusion-induced superoxide generation in arterial wall and cell death in skeletal skeletal muscle. J Pineal Res. 2006:41(3):255-60.

21. Wang WZ, Fang XH, Stepheson LL, Khiabani KT, Zamboni WA. NOS upregulation attenuates vascular endothelial dysfunction in the late phase of ischeamic preconditioning in skeletal muscle. J Orthop Res. 2004; 22(3):578-85.

22. Xiao YD, Liu YQ, Li JL, Ma XM, Wang YB, Liu YF, et al. Hyperbaric oxygen preconditioning inhibits skin flap apoptosis in a rat ischemia-reperfusion model. J Surg Res. 2015;199(2):732-9.

23. Knox LK, Stewart AG, Hayward PG, Morrison WA. Nitric oxide synthase inhibitors improve skin flap survival in the rat. Microsurgery 1994;15:708-711.

24. Bandera BC, Pham T, Hill-Pryor C, Bah-Sow M, Franco N, Prasad $\mathrm{BM}$, et al. Role of growth factors in improved skin flap viability caused by phosphodiesterase-5 inhibitor. Am Surg 2010;76: 614-617.

25. Senthilkumar A, Smith RD, Khitha J, Arora N, Veerareddy S, Langston W, et al. Sildenafil promotes ischemia-induced angiogenesis through a PKG-dependent pathway. Arterioscler Thromb Vasc Biol 2007:27:1947-1954.

26. Sundaresan M, Yu ZX, Ferrans VJ, Sulciner DJ, Gutkind JS, Irani K, et al. Regulation of reactive-oxygen-species generation in fibroblasts by Rac1. 2Biochem J. 1996;31

27. Marques Araujo BS, Duval Vidigal I, Vieira Teixeira Mayrink P, Alvarenga Campos Araujo C, Duval A, Costa PR. Effects of sildenafil on the viability of random skin flaps. Acta Cirurgica Brasileira. 2011; 26(4):314-319.

28. Karamatsoukis SL, Trigka EA, Stasinopoulou M, Stavridou A, Zacharioudaki A, Tsarea K, et al. Beneficial Effect of U-74389 G and Sildenafil in An Experimental Model of Flap Ischemia/Reperfusion Injury in Swine. Histological and Biochemical Evaluation of the Model. J Invest Surg. 2020;33(5):391-403.

29. Tu Q, Cao H, Zhong W, Ding B, Tang X. Atorvastatin protects against cerebral ischemia/reperfusion injury through antiinflammatory and antioxidant effects. Neural regeneration research. 2014;9(3):268-275.

30. Castro MM, Rizzi E, Rascado RR, Nagassaki S, Bendhack LM, Tanus-Santos JE. Atorvastatin enhances sildenafil-induced vasodilation through nitric oxide-mediated mechanisms. European Journal of Pharmacology. 2004;498(1-3):189-194.

31. Kelahmetoglu O, Demir R, Okten G, Demir A, Alpaslan Pinarli F, Diraman $E$. The effect of mesenchymal stem cells and sildenafil on flap viability in perforator-based flaps for ischemia/reperfusion injury: An experimental study. Microsurgery. 2016;36(5):402-409.

32. Mohey V, Singh M, Puri N, Kaur T, Pathak D, Singh AP. Sildenafil obviates ischemia-reperfusion injury-induced acute kidney injury through peroxisome proliferator-activated receptor - agonism in rats. J Surg Res. 2016;201(1):69-75. 